METALLURGY AND FOUNDRY ENGINEERING - Vol. 35, 2009, No. 1

Małgorzata Rutkowska-Gorczyca*, Marzena Podrez-Radziszewska*, Jerzy Kajtoch**

\title{
CORROSION RESISTANCE AND MICROSTRUCTURE OF STEEL AISI 316L AFTER COLD PLASTIC DEFORMATION
}

\section{INTRODUCTION}

Common use of metallic implants in medicine should evidence their very good properties but in great many cases they still do not meet the requirements. A basic criterion for this group of materials is biotolerance that measure is corrosion resistance. Low corrosion resistance of metallic biomaterials can lead to the metalosis phenomenon and to decreasing mechanical properties of a given material [1]. One of the most frequently used metallic materials is steel AISI $316 \mathrm{~L}$, that is also one of the cheapest materials used for short-term implants. It is characterised by high strength and easy machining but its corrosion resistance is still insufficient. In order to improve bioconformity and corrosion resistance with maintained mechanical properties, these materials are subject to surface treatment [2].

Modification of the surface layer should result in obtaining a thin layer of homogeneous structure with high strength, functionality and corrosion resistance. One of the methods used in order to improve properties of implant steels is modification of their chemical composition and applying protective coatings on the metallic substrate. Depending on the applied method, a large spectrum of material properties can be obtained. One of the newest methods of applying surface layers in the detonation method. During detonation spraying, thermal energy of powder particles chaotically propagates at the moment of their collision with the base material. In the subsurface layer, the colliding particles cause plastic deformation and, consequently, local cold work and thus strain hardening of the material [3, 4].

* M.Sc., Ph.D.: Institute of Materials Science and Applied Mechanics, Wroclaw University of Technology, Wroclaw, Poland; malgorzata.rutkowska-gorczyca@pwr.wroc.pl

** Ph.D.: Faculty of Metals Engineering and Industrial Computer Science, AGH - University of Science and Technology, Krakow, Poland; kajtoch@metal.agh.edu.pl 
The plastic deformation results in cleaning the base material surface and creating a physical contact with the particles, as well as leads to concentration of dislocations. Changes in the material microstructure caused by cold working result in changed physico-chemical properties, strictly related to corrosion resistance of the modified material.

\section{MATERIAL AND METHODOLOGY}

The material for testing was austenitic steel AISI 316L delivered as 1-mm thick sheet cold-rolled and annealed, with chemical composition given in Table 1.

As examined, microstructure of the delivered material was austenitic with numerous recrystallisation twins, see Figure 1 . With respect to chemical composition and level of impurities, the steel meets the requirements of PN-ISO 5832-1:1997.

Table 1. Chemical composition of steel AISI 316L

\begin{tabular}{|c|c|c|c|c|c|c|c|c||}
\hline $\mathrm{C}$ & $\mathrm{Mn}$ & $\mathrm{Si}$ & $\mathrm{P}$ & $\mathrm{S}$ & $\mathrm{Cr}$ & $\mathrm{Ni}$ & $\mathrm{Mo}$ & $\mathrm{Cu}$ \\
\hline 0.02 & 1.00 & 0.38 & 0.010 & 0.006 & 16.25 & 10.75 & 2.35 & 0.20 \\
\hline
\end{tabular}

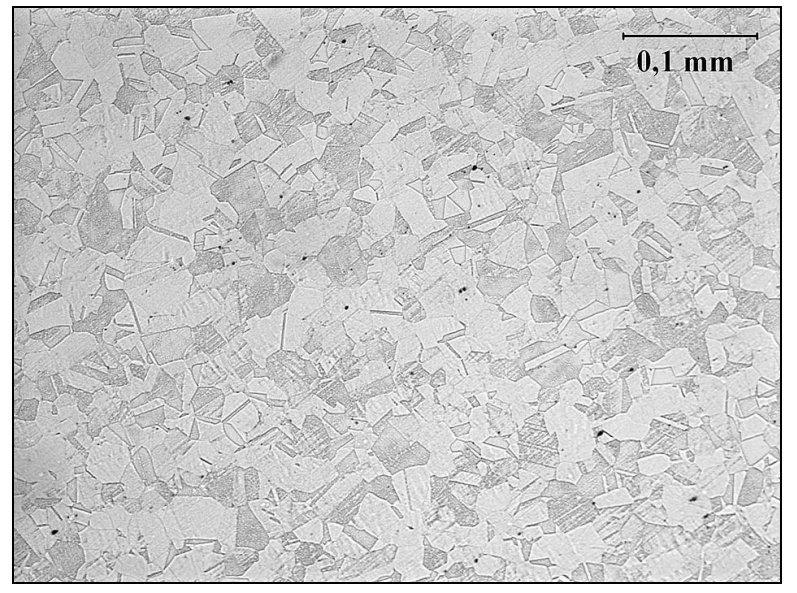

Fig. 1. Microstructure of steel AISI $316 \mathrm{~L}$ as-delivered: austenitic structure with recrystallisation twins. Light microscopy, etched

Steel sheets $50 \mathrm{~mm}$ wide and $250 \mathrm{~mm}$ long were subject to cold rolling to obtain strips 0.9 to $0.5 \mathrm{~mm}$ thick with the cold working ratios of $10,20,30,40$ and $50 \%$.

Cold rolling was performed at the Department of Metal Working of AGH University of Science and Technology in Krakow, on a rolling mill quarto L200 that enabled reversing rolling of thin strips with back tension. Layout of the mill is shown in Figure 2. The test stand permitted recording pressure forces and rotational speed of the roll as well as tension forces [5]. 


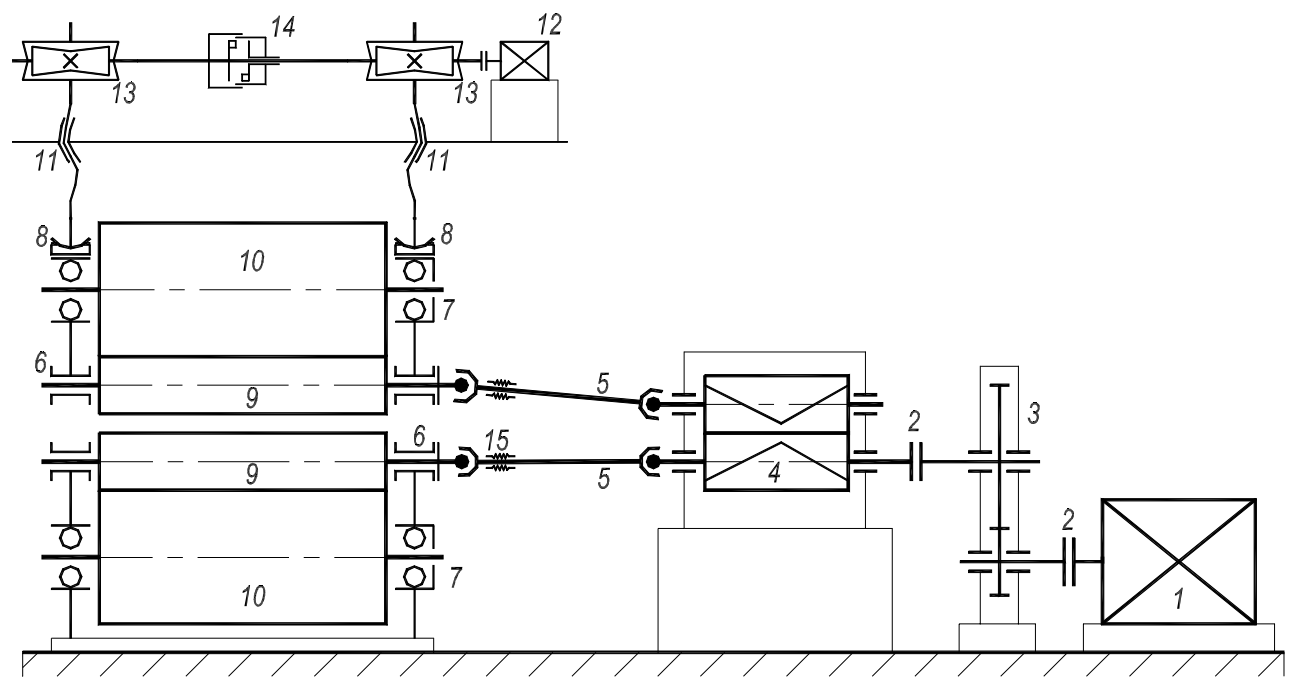

Fig. 2. Kinematic layout of a laboratory rolling mill quarto L200 [5]: 1 - main drive motor, 2 -jaw coupling; 3 -toothed reduction gear; 4 - rolling stand; 5 -wobbler coupling; 6 - slide bearings of working rolls; 7 - double-row barrel bearings of backing rolls; 8 - tensometric strain gauges for pressure force measurements or membrane safety devices; 9 - working rolls $\varnothing 100 \times 200 \mathrm{~mm}$; 10 - backing rolls $\varnothing 400 \times 200 \mathrm{~mm} ; 11$ - pressure bolts; 12 -drive motor of rolling gap control; 13 - worm gear; 14 - synchronic coupling; 15 - strain gauge for torque measurement

Because of high flow stress of the examined steel after cold rolling and spring mounting of the upper roll, obtaining large plastic deformations in one pass was impossible. In practice, the cold working ratio in one pass did not exceed $20 \%$ (on non-hardened material) and the ratio declined along with the material hardening degree. As a result, higher cold working ratios (over 20\%) could be obtained in several passes only, by pressing down the rolls subsequently.

Specimens for potentiodynamic tests were in form of disks dia. $14.7 \mathrm{~mm}$ cut-out from the sheets subject to cold working. Directly before testing, the specimens were ground and polished. For stabilizing, each specimen before measurement was immersed for 20 minutes in the Ringer solution. Measurements were taken at $20^{\circ} \mathrm{C}$.

Electrochemical direct-current measurements in order to determine corrosion resistance consisted in measuring the open circuit potential and recording the relationship $i=f(E)$ during polarisation tests in a three-electrode measurement system. The system consisted of a measuring vessel, potentiostat Atlas 0531 (Elektrochemical Unit and Impedance Analyser) and a computer controller. Two electrodes were used: an austenitic auxiliary one and a reference one in form of a saturated electrode $\mathrm{Ag} / \mathrm{AgCl}$.

The tests were performed in the Ringer solution containing $8.6 \mathrm{~g} / \mathrm{l}$ of sodium chloride, $0.3 \mathrm{~g} / \mathrm{l}$ of potassium chloride and $0.48 \mathrm{~g} / \mathrm{l}$ of calcium chloride hexahydrate. Selection of the corrosive medium was related to application of the examined steel for medical implants and was aimed at simulating the environment of physiological fluids. After 20 minutes of 
staying in the solution, the specimens in the same solution were subject to polarisation in anode direction at the velocity $d E / d t=1 \mathrm{mV} / \mathrm{s}$. Values of current and corrosion potential were determined using the Stern method by extrapolation of the Tafel lines for anodic and cathodic sections of the curve $i=f(E)$ within $\pm 40 \mathrm{mV}$ from the measured potential of the cathodic-anodic transition.

Microscopic examination after cold working were performed using a light microscope Neophot 32 and surfaces of the specimens after corrosion tests were observed using an electron scanning microscope JEOL JSM-5800LV to record the occurred corrosion changes.

\section{ANALYSIS OF RESULTS}

Microscopic examination was carried out on all the specimens to determine the microstructure changes caused by cold working. Analysis of the deformed microstructure revealed numerous slip bands in austenite grains (Fig. 3a). At the highest cold working ratio of $50 \%$ (Fig. $3 \mathrm{~b}$ ), the slip lines are not clearly visible because of strong microstructure deformation and texture.

a)

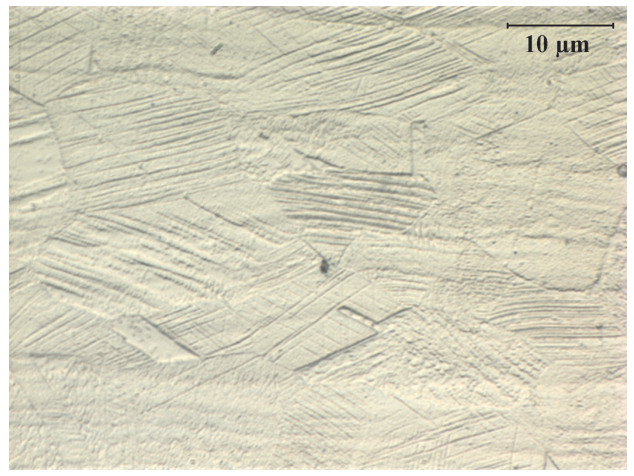

b)

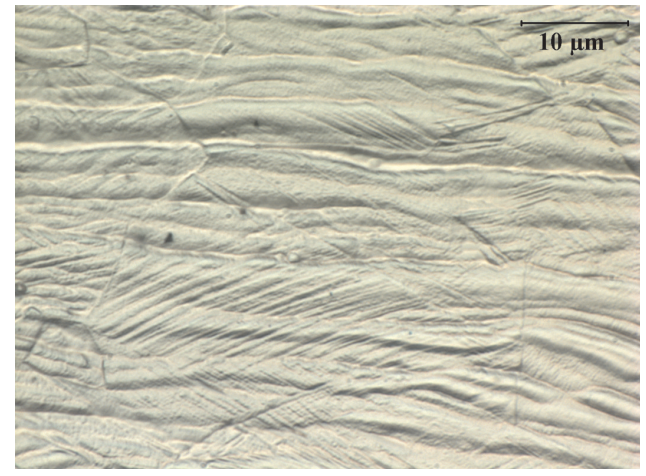

Fig. 3. Changes of microstructure caused by cold working $10 \%$ (a), $50 \%$ (b) Cross-section LM

Strain hardening of steel after cold working was determined by Vickers hardness measurements, see Figure 4. On their ground, a double increase of hardness was found, from $168 \mathrm{HV} 1$ for the material as-delivered to $368 \mathrm{HV} 1$ for the material with cold working ratio of $50 \%$.

In the potentiodynamic tests, open-circuit (stationary) potentials of the specimens were determined. It was found that this potential declines along with increasing cold work ratio. The obtained potential values changed in a wide range from the positive value $+456 \mathrm{mV}$ for the material as-delivered to the negative value $-954 \mathrm{mV}$ for a specimen with $50 \%$ cold working ratio. The potential is determined by the ion exchange processes occurring between the specimen and the corrosion solution. So, the decidedly lower potential values of 
the non-polarised specimens should be related to passivation ability of steel in the corrosion medium, what becomes worse with higher cold deformation degree. The open-circuit potential values for the specimens with different cold working ratios are given in Table 2.

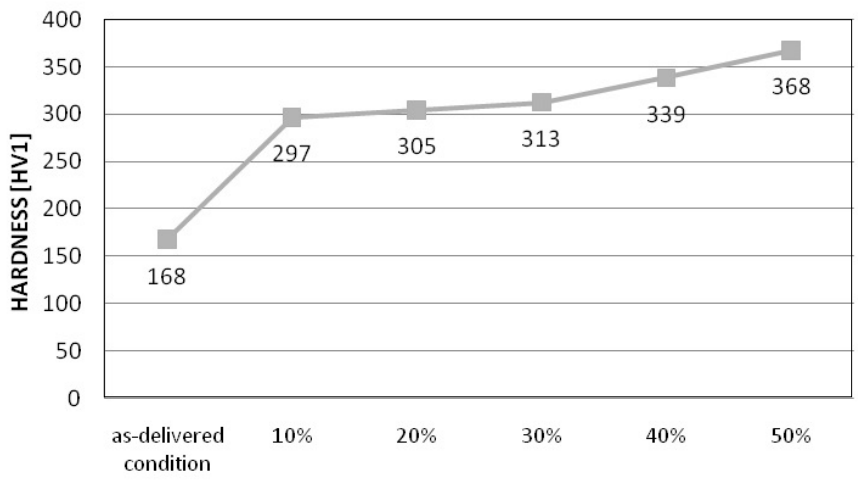

Fig. 4. Effect of cold working on hardness

Table 2. Open-circuit potential values

\begin{tabular}{|c|c|c|c|c|c|c||}
\hline Cold working, \% & As-delivered condition & 10 & 20 & 30 & 40 & 50 \\
\hline $\mathrm{E}, \mathrm{mV}$ & 456 & 188 & -115 & -459 & -578 & -954 \\
\hline
\end{tabular}

For the specimens with various cold work ratios, polarisation curves were drawn, showing the relationship between voltage and current density, see Figure 5. Shape of the polarisation characteristics was similar for all the examined specimens. Similar current densities were found in cathodic ranges of the polarisation curves, but clear increase of current density with cold working ratio was observed in anodic ranges. Analysis of the curves indicates a clear tendency for decreasing the cathodic-anodic transition potential and increasing the currents for this potential along with increasing strain hardening. In the course of the curves, a clear stability loss of the current density is observed, related to the changes occurring in the passive material layer. Along with increasing cold working ratio, these changes were observed at lower and lower potential values. The corrosion potential $E_{k o r}$ and current $I_{k o r}$ values were determined by extrapolation of the Tafel curves, see Table 3.

The corrosion potential value was $-38.5 \mathrm{mV}$ for the as-delivered material and declined to $-115.7 \mathrm{mV}$ for the specimen with $50 \%$ cold working ratio. Such a potential difference is sufficient for corrosion occurrence in the case when some places with differentiated cold deformation degree exist in the material. The corrosion current density increased over 12 times from $12 \mathrm{nA} / \mathrm{cm}^{2}$ for the as-delivered material to $148 \mathrm{nA} / \mathrm{cm}^{2}$ for the specimen with maximum cold working ratio. The measurement results for all the specimens are settled in Table 3. 


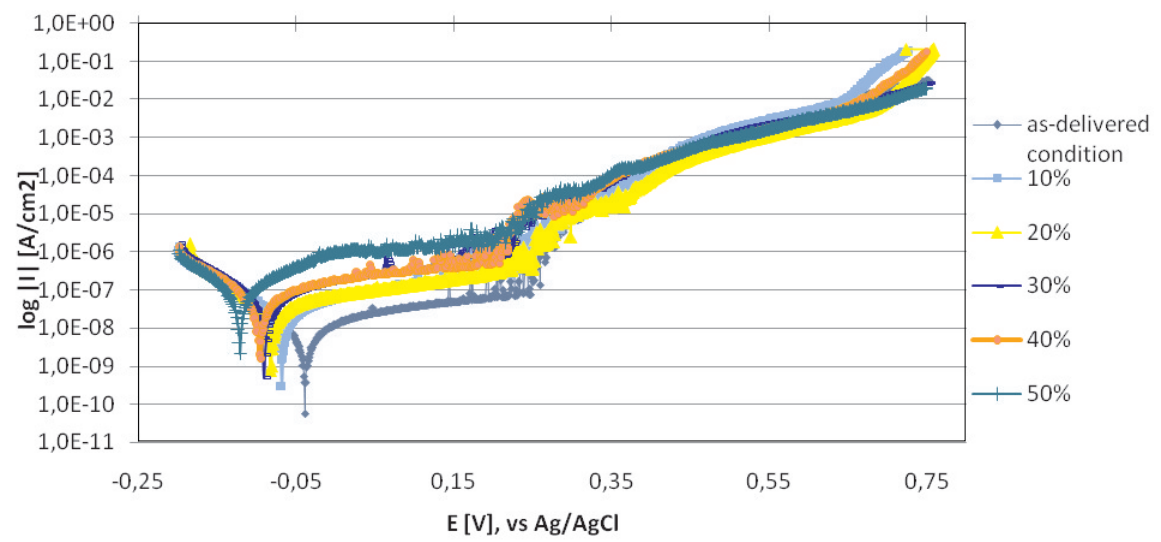

Fig. 5. Polarisation curves determined in Ringer solution for AISI $316 \mathrm{~L}$ steel specimens subject to various cold working ratios (as-delivered and 10 to 50\%)

Table 3. Potential and corrosion current values

\begin{tabular}{|c|c|c|c|c|c|c||}
\hline $\begin{array}{c}\text { Cold working, } \\
\%\end{array}$ & $\begin{array}{c}\text { As-delivered } \\
\text { condition }\end{array}$ & 10 & 20 & 30 & 40 & 50 \\
\hline $\mathrm{E}_{\mathrm{kor}}, \mathrm{mV}$ & -38.5 & -67.8 & -103.7 & -90.5 & -95.6 & -115.7 \\
\hline $\mathrm{I}_{\mathrm{kor}}, \mathrm{A} / \mathrm{cm}^{2}$ & $12.4 \times 10^{-9}$ & $52.8 \times 10^{-9}$ & $62.4 \times 10^{-9}$ & $94.4 \times 10^{-9}$ & $120.4 \times 10^{-9}$ & $147.7 \times 10^{-9}$ \\
\hline
\end{tabular}

The results indicate that corrosion resistance of the austenitic steel declines with increasing strain hardening degree. Shorter thermodynamic durability of strain-hardened steel increases probability of corrosion occurrence. This shortened thermodynamic durability is attributed to its increased internal energy. Injured tightness of the passive layer is determined as another cause of worsened corrosion resistance of the steel [6].

Microscopic observations of the specimens after corrosion tests revealed pits on their surfaces. It was found that intensity as well as size and depth of the pits is dependent on cold working ratio of the specimens, see Figure 6. Along with increasing cold working ratio, more and more numerous pits were observed. On the specimen in the as-delivered condition, small, round and not very deep pits were observed on the surface, see Figure 6a. The most intensive and extensive changes were recorded on the specimen with $50 \%$ cold working ratio, see Figure $6 \mathrm{~d}$. A number of holes distributed around the pit mouth was observed. Nature of the pits was similar to that of the pits obtained in [7], also in the environment containing $\mathrm{Cl}^{-}$ions. Ernst et al. [8] showed that pit growth in depth follows a parabolic law with time and is independent on the potential. The lateral growth is essentially a sequence of deterministic undercutting events, each resembling growth of a metastable pit. Growth of lateral pit is linear with time and dependent on the potential. 
a)

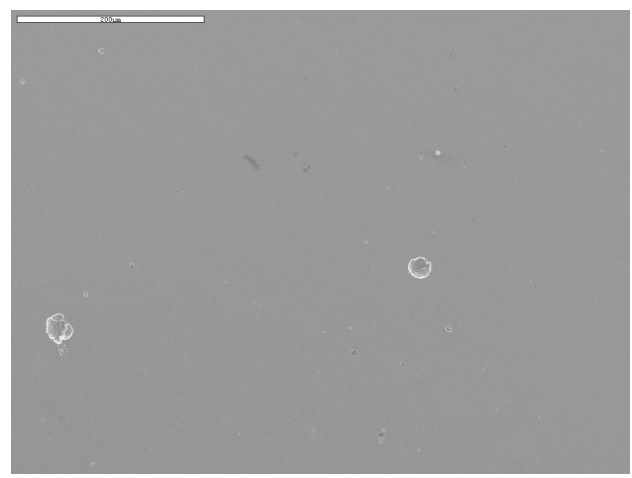

c)

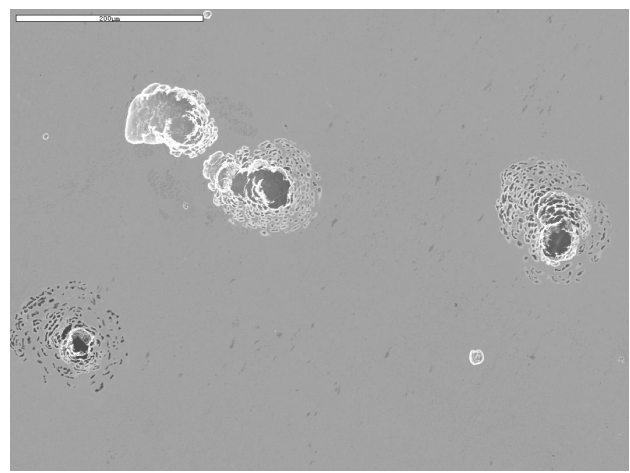

b)

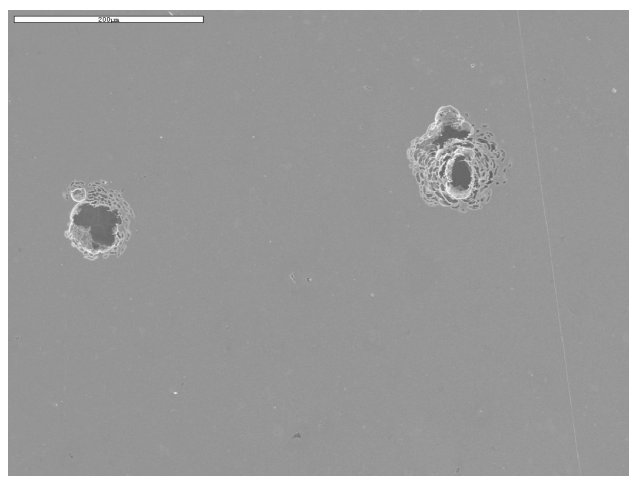

d)

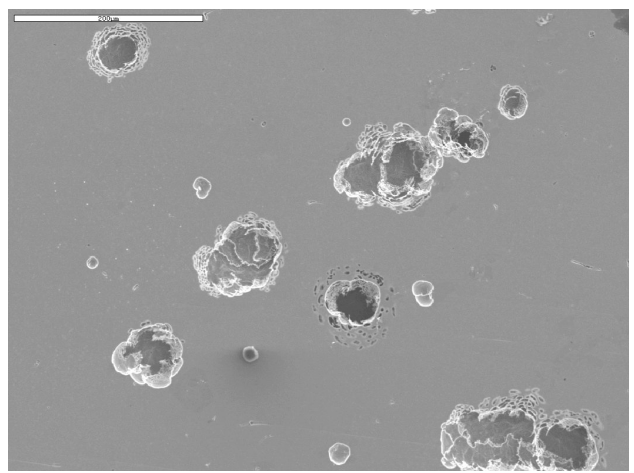

Fig. 6. Surfaces of specimens after corrosion tests. Intensity of corrosion pits increases with cold working ratio: as-delivered condition (a), 20\% (b), 30\% (c), 50\% (d), SEM

\section{CONCLUSION}

The research was aimed at evaluating influence of cold working ratio on corrosion resistance of the austenitic steel AISI 316L. To determine the microstructure changes after cold plastic deformation, metallographic examinations were performed and hardness measured. Microscopic observations revealed changes caused by plastic deformation in form of numerous slip bands within austenite grains. With increasing cold working ratio, more and more numerous slip bands are visible, however at $50 \%$ cold working ratio the slip bands disappear as a result of strong material deformation.

The research revealed distinct hardness increase of cold-worked steel, from $168 \mathrm{HV} 1$ for the as-delivered material to $368 \mathrm{HV} 1$ for the material with the highest cold working ratio. The hardness increase is related to strain hardening caused by cold plastic deformation.

The research revealed also a clear drop of corrosion resistance of the deformed material. The corrosion tests showed the following changes occurring with increasing cold working ratio: 
- Potential in non-polarised specimens emphatically drops from positive values for the as-delivered material to negative values for the specimen with maximum applied strain hardening. The so significant difference of stationary potentials proves loss of thermodynamic durability of cold-worked specimens.

- Corrosion potential decrease is accompanied by increase of corrosion current. This proves faster initiation of corrosion processes and their higher intensity at higher cold working ratios.

- Polarisation curves show stability loss of current density in their anodic sections. This should be related to destroying the passive layer. Analysis of the curves for all the specimens shows that this stability loss in function of cold working ratio occurs at lower and lower potentials. This proves that the higher strain hardening degree of the examined steel, the faster is the passive layer destroyed.

- Local deformation (provoked e.g. by machining or applying surface layers) results in creating non-homogeneous structure with locally reduced corrosion resistance. Behaviour of the non-homogeneous material is schematically is shown in Figure 7. The area marked " $\mathrm{A}$ " is characterised by higher plastic deformation degree and thus lower corrosion potential with respect to "B". As a result, the area "B" shows anodic nature with respect to the remaining material, so the corrosion processes will be initiated on it.

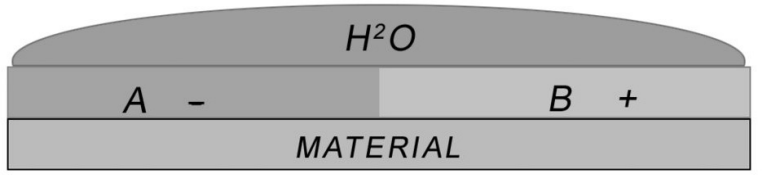

Fig. 7. Diagram of corrosive behaviour of the material with non-homogeneous deformation

\section{Acknowledgements}

This scientific work was financed from the means of Wroclaw University of Technology by the Development Grant No. 332727/I19 and the Internal Promotion Grant No. 332123.

\section{REFERENCE}

[1] Lechosław F., Krasicka-Cydzik E., Mstowski J., Zarzycki D.: Metalowe implanty kręgosłupowe. Systemy Dero: Rozwój technik operacyjnego leczenia kręgosłupa, 2-Sympozium, Zielona Góra (1997), 93-105

[2] Przybyszewska-Doroś I., Okrój W., Walkowiak B.: Modyfikacje powierzchni implantów metalicznych, Inżynieria Biomateriałów (2005), 52-63

[3] Jeleńkowski J., Borkowski T., Babul T.: Zmiany w strukturze strefy pośredniej podczas natryskiwania detonacyjnego, Inżynieria Materiałowa. 29 (2008) 6, 595-597

[4] Babul T.: Połączenie powłoka-podłoże uzyskiwane metodą wybuchową i detonacyjną, Inżynieria Materiałowa. 20 (1999) 6, 623-627 
[5] Sińczak J., Kajtoch J., i in.: Procesy przeróbki plastycznej, Wyd. Nauk. AKAPIT, Kraków 2003

[6] Tomaszow N.D.: Teoria korozji i ochrony metali. PWN, Warszawa 1962 (in polish)

[7] Krasicka-Cydzik E.: Badania wpływu obróbki powierzchniowej na odporność korozyjną stali implantowych. Archiwum Technologii Maszyn i Automatyzacji, 17 (1997) 1, 173-183

[8] Ernst P., Newman R.C.: Pit growth studies in stainless steel foils, I. Introduction and pit growth kinetics. Corrosion Science 44 (2002), 927-941

Received

November 2009 